\begin{tabular}{|c|c|}
\hline & $\begin{array}{l}\text { Omni-Akuatika Special Issue } 3^{\text {rd }} \text { Kripik SCiFiMaS 2020: } 92 \text { - } 98 \\
\text { ISSN: } 1858-3873 \text { print / 2476-9347 online }\end{array}$ \\
\hline & Research Article \\
\hline & journal homepage: http://ojs.omniakuatika.net \\
\hline
\end{tabular}

\title{
The Biological Aspect of Mackerel Scad (Decapterus Macarellus Cuvier, 1833) In Samudera Hindia (West Sumatera Block)
}

\author{
Heri Widiyastuti ${ }^{\star}$, Andina Ramadhani Putri Pane, Moh Fauzi, and Thomas Hidayat \\ Research Institute of Marine Fisheries, Ministry of Maine affairs and Fisheries, Bogor Indonesia 16912 \\ *Corresponding author : heriwidiyastuti@gmail.com
}

Received 20 November 2019; Accepted 1 October 2020; Available online 31 December 2020

\begin{abstract}
Mackerel scad (Decapterus macarellus) is one of the important economical caught in the Indian Ocean West Sumatra waters captured using purse seine. Increased production of mackerel scad will lead to increased exploitation, causing population changes. Therefore, research was carried out to find out the biological aspects of the fish so that resource management can be done. The sampling was conducted in Lampulo, Sibolga, and Air Bangis from February to November 2016 with total samples of 716 fishes. This research was conduct to study some biological aspects which consist of size distribution, lengthweight relationship, sex ratio, gonad maturity level, the length at first capture, and length of the first maturity in Indian ocean west Sumatera waters. The results showed that the size of the mackerel scad had ranged between $16-33.6 \mathrm{~cm} \mathrm{FL}$ and the average was $24.5 \mathrm{~cm}$. Growth patterns are allometric negative, sex ratio male and female in an unbalanced condition. The mackerel scad is most caught by purse seine in maturity condition. The average length at first captured was $25.08 \mathrm{~cm}$ FL and length at first mature was $20.47 \mathrm{~cm}$ FL. These were an ideal biological condition and must be maintained because it provides an opportunity for fish to increase the population. The mesh size purse must follow the Ministry of Maritime Affairs and Fisheries Regulation Number 71/2016 that adjusted for minimum at 1 inch.
\end{abstract}

Keywords: Mackerel scad, Indian Ocean, Purse seine

\begin{abstract}
ABSTRAK
Ikan layang biru (Decapterus macarellus) adalah salah satu hasil tangkapan ekonomi penting di perairan Samudra Hindia Sumatera Barat yang ditangkap menggunakan purse seine. Peningkatan produksi ikan layang biru akan menyebabkan peningkatan eksploitasi dan menyebabkan perubahan populasi. Oleh karena itu, penelitian dilakukan untuk mengetahui aspek biologis ikan sehingga pengelolaan sumber daya dapat dilakukan. Pengambilan sampel dilakukan di Lampulo, Sibolga, dan Air Bangis dari Februari hingga November 2016 dengan total sampel 716 ikan. Penelitian ini dilakukan untuk mempelajari beberapa aspek biologis yang terdiri dari distribusi ukuran, hubungan panjangberat, rasio jenis kelamin, tingkat kematangan gonad, panjang pada tangkapan pertama, dan panjang jatuh tempo pertama di Perairan Samudera Hindia Barat Sumatera. Hasil penelitian menunjukkan bahwa ukuran panjang ikan layang biru dalam kisaran panjang antara $16-33,6 \mathrm{~cm}$ FL dan modus ukuran adalah $24,5 \mathrm{~cm}$. Pola pertumbuhan allometrik negatif, rasio jenis kelamin jantan dan betina dalam kondisi tidak seimbang. Ikan layang biru paling banyak ditangkap oleh purse seine dalam kondisi matang gonad. Panjang rata-rata pertama kali tertangkap (Lc) adalah 25,08 cm FL dan panjang pertama matang gonad $(\mathrm{Lm})$ adalah $20,47 \mathrm{~cm}$ FL. Hal ini adalah kondisi biologis yang ideal dan harus dipelihara karena memberikan peluang bagi ikan untuk meningkatkan populasi. Ukuran mata jaring purse seine harus mengikuti Peraturan Menteri Kelautan dan Perikanan Nomor 71/2016 yaitu minimum 1 inci.
\end{abstract}

Kata kunci: Ikan layang biru, Samudra Hindia, Purse seine 


\section{Introduction}

The Indian Ocean is fertile water and has the potential of pelagic fish and enter into fisheries management area 572. The main fishing gear of pelagic fisheries in this area was purse seine. the fishing ground of purse seine covering the waters of South Aceh, North Sumatera to the border with the waters of West Sumatra to the Mentawai Islands (Hariati, 2015).

Habitat mackerel scad widely found in deep seawater, its spread influenced by high salinity. The distribution of mackerel scad is throughout Indonesia's waters. In general, these fish caught throughout the year in Ambon waters, but the distributions of scad mackerel fish in Indonesia include the Java Sea, Strain of Makassar, Ambon, Ternate (East Indonesia) (Tiews et al., (2001) in Silooy et al., 2019). Whereas in western Indonesia one of them is in the Indian Ocean Mackerel scad (Decapterus macarellus) is the dominant species caught by purse seine in The Indian Ocean West Sumatra waters.

Zamroni and Suwarso (2017) state that the catch and index of abundance of this fish have increased from 2012 to 2013 by $1.3 \%$ or around 444 tons. Increased production is an indication of an increase in resource exploitation, if it occurs continuously will cause population decline. The occurrence of population changes can be seen from changes in fish biological characteristics such as changes in structure, sex ratio, gonad maturation level, and the relationship of body weight with body length. Ansyari \& Herlan (2013) state research into changes in these biological aspects will form the basis of rational management.

The research of mackerel scad has been done the waters of in the eastern part of Indonesia (Zamroni, \& Suwarso, 2011;

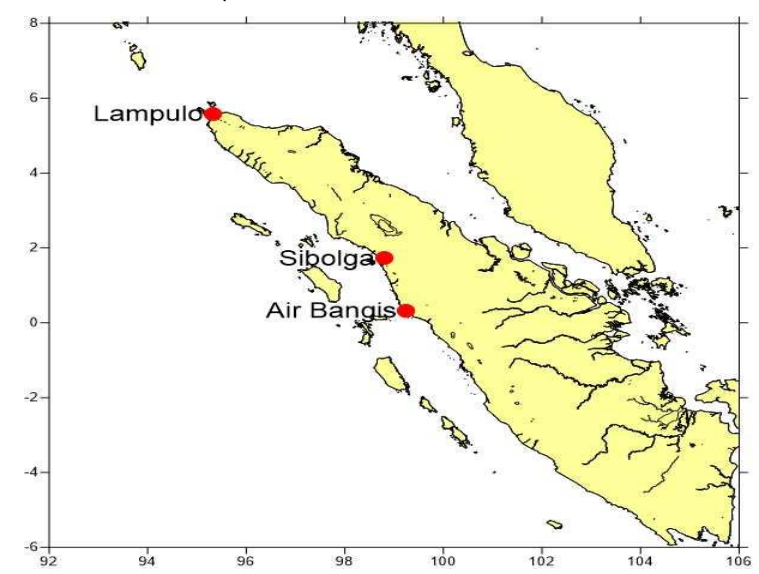

Figure 1. Map of study area
Rahmadi, \& Puspasari, 2015; Fadilal, et al., 2016; Widiyastuti \& Zamroni, 2017; Pattikawa, et al., 2018; Widiyastuti, et al., 2020; Widiyastuti \& Herlisman, to be published), while the research on biological mackerel scad, especially in the Indian Ocean West Sumatera waters has not been much performed (Hariati, 2005; Zamroni \& Suwarso, 2018; Rumpa \& Isman, 2018) especially about aspect biological. For this reason, this research is important and was conducted to study some biological aspects which consist of size distribution, growth pattern, sex ratio, gonad maturity, and the length at first capture (Lc) and the length at first maturity (Lm) mackerel scad (D. macarellus) in Indian ocean west Sumatera waters. This research was conducted to understand the biological aspect of mackerel scad as a consideration on arranging a proper management.

\section{Materials and methods}

\subsection{Sampling site and data collections}

Mackerel scad samples collected from the purse seine at Lampulo, Sibolga, and Air Bangis (Figure 1). The study was conducted from February to November 2016. The total sample of the mackerel scad collected 716 samples with the random sampling method (Figure 2). Mackerel scad samples carried out fork length (FL) measurements using measuring paper and body weight measured with a digital scale.

Then fish that have been measured fork length and weight will be dissected to observe the sex and maturity of the gonads. The observation of the gonads was conducted morphologically and was determined based on the modification of the Cassie classification (Effendie, 2002).

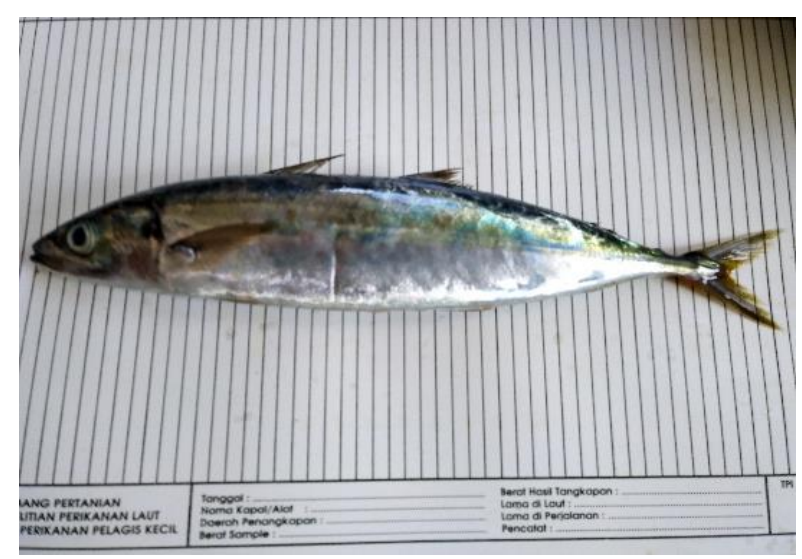

Figure 2. Mackerel Scad (Decapterus macarellus) 


\subsection{Data Analysis}

The length structure of the fish fork tabulated by the frequency of fish numbers analyzed at each interval of the length class. Then analysis length-weight relationship using (Pauly, 1984) :

$$
\mathrm{W}=\mathrm{a} \mathrm{L}^{\mathrm{b}} \ldots
$$

Where:

$$
\begin{aligned}
& W=\text { weight }(\mathrm{g}) ; \\
& \mathrm{L}=\text { Total length }(\mathrm{cm}) ; \\
& \mathrm{a}=\text { intercept; } \\
& \mathrm{b}=\text { slope. }
\end{aligned}
$$

The interval value of slope (b) at $p=0.05$ was calculated according to (King, 2007):

$$
\mathrm{b} \pm \mathrm{t} x \mathrm{sb}
$$

Where: $\mathrm{t}=\mathrm{t}$ table $(\mathrm{p}=0.05 ; \mathrm{df}=\mathrm{n}-2) ; \mathrm{sb}=$ standard deviation of $b$

The sex ratio is analyzed by comparing the number of male and female fishes (Effendie, 2002).

$$
X=M / F
$$

Where :

$$
\begin{array}{ll}
X & =\text { sex ratio, } \\
M & =\text { number of males, } \\
F & =\text { number of female. }
\end{array}
$$

Then the sex ratio was analyzed by the Chi-square test (Walpole, 1993) to find out the balance of male and female compositions.

The analysis of biological data includes distribution fork-length, the average length captured $(\mathrm{L} 50 \%=\mathrm{Lc})$ and length at first mature $(\mathrm{Lm})$, sex-ratio, length-weight relationships. The average length at first captured (Lc) was analyzed using the Kerstan equation (Kerstan, 1985):

$$
Y(\%)=\left[\frac{100}{\left(1+a * e^{-b} * x\right)}\right]
$$

Where:

$Y(\%)=$ proportion held at each point of long class

$\mathrm{a}=$ intercept

$\mathrm{b}=$ Slope

$\mathrm{e}=$ exponential

$\mathrm{x}=$ length captured $(\mathrm{L}-50 \%)$

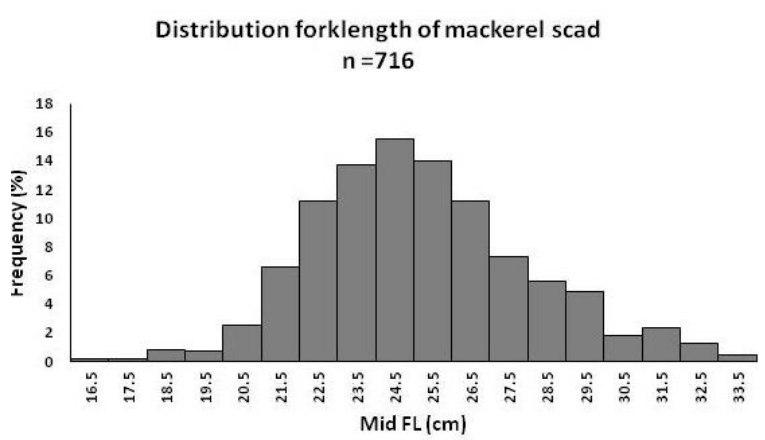

Figure 3. Distribution fork-length of mackarel scad
The gonad maturity stage determined visually according to five point maturity scale for partial spawners refers to Holden \& Raitt (1974). Stage I: virgin, immature; Stage II: development (maturing); Stage III: ripening; Stage IV: mature or ripe; and Stage V: spent.

The length at first mature (Lm) was allegedly by the Spearmean-Karber way as proposed by Udupa (Udupa, 1986) as follows:

$$
\mathrm{m}=\mathrm{xk}+\frac{X}{2}-\left(X \sum p i\right)
$$

Where:

$\mathrm{m}=$ Log length at first mature

$\mathrm{xk}=$ Log mid-class value where all fish $(100 \%)$ Already ripe gonad

pi $=$ Proportion of ripe fish in the first class where $\mathrm{Pi}=\mathrm{ri} / \mathrm{ni}$ when $\mathrm{ni}=\mathrm{ni}+\mathrm{L}$

$\mathrm{RI}=$ the number of ripe fish in the length class to-I then the length of the fish at the time reaches the first maturity $(M)$ is $M=$ Antilog (M).

If the confidence level of $95 \%(A=0.05)$ of $(m)$ is used, then the range is an antilog $(m \pm$ $1.96 \sum(\times 2$ (Pi-qi/ni-1)).

\section{Results and discussion}

\subsection{Distribution length}

The length distribution of the study ranged from 16.0-33.6 cm FL (Figure 3). The highest mode is located at the mid-length value of $24.5 \mathrm{~cm} \mathrm{FL}$. The longest fish structure was found in October, while the fish size was shorter in August (Table 1). Even the size structure of this water tends to be longer than other waters (Table 2).

This difference in size structure can be caused by differences in the mesh size used and the fertility of the waters (Pane et al., 2020). These waters have high chlorophyll levels and phytoplankton as primary productivity (Merina et al., 2016). Sufficient food will support the growth of fish body length.

\subsection{Length-weight relationship}

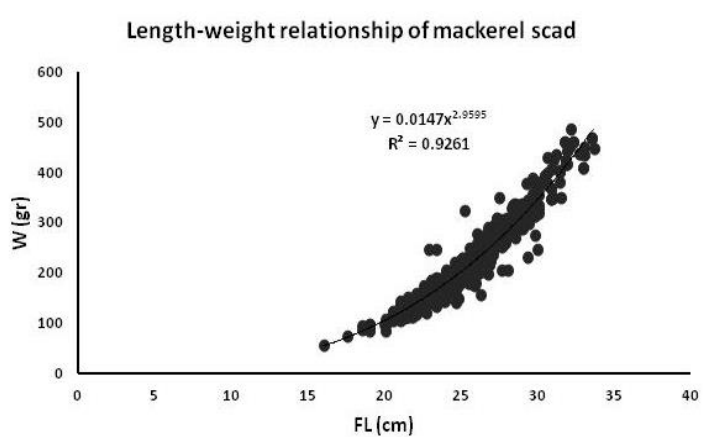

Figure 4. Length-weight relationship of mackerel scad 
Table 1. Monthly length distribution of mackerel scad

\begin{tabular}{cccccc}
\hline Month & N & Min & Max & Fork Length (cmFL) & Average \\
\cline { 3 - 5 } & 63 & 21.0 & 30.0 & 25.51 & Standard Deviation \\
\hline Feb & 92 & 16.0 & 29.0 & 22.29 & 1.69 \\
Mar & 111 & 20.0 & 29.0 & 24.29 & 1.90 \\
Jun & 42 & 20.8 & 29.8 & 25.58 & 2.54 \\
Aug & 238 & 18.5 & 33.6 & 26.72 & 3.24 \\
Oct & 170 & 21.2 & 32.1 & 25.70 & 2.01 \\
Nov & & & &
\end{tabular}

Table 2. Prevoius research results

\begin{tabular}{lll}
\hline Reference & Waters & FL (cm) \\
\hline Fadilal et al., 2016 & Banda Sea & $11.4-29.5$ \\
Widiyastuti \& Zamroni, 2017 & Tomini Bay & $17.25-30.25$ \\
Pattikawa et al., 2017 & Ambon & $11-24.5$ \\
Widiyastuti et al., 2020 & Ambon & $10.5-29.5$ \\
Widiyastuti \& Herlisman, to be published & Kendari & $17.5-30.5$ \\
This study & Indian ocean of Western Sumatera & $16-33.6$ \\
\hline
\end{tabular}

The length-weight relationship of the mackerel scad resulted in the value of $b$ was 2.959, this indicates a negative allometric growth pattern where a regression coefficient value $(b)$ is less than $3(b<3)$ (Figures 4$)$. It is meanings that fish grow faster in length than the bodyweight gain.

The same results were obtained by mackerel scad growth patterns in the North Maluku waters. The males and females of mackerel scad each have a value of $b=2.285$ and $b=2.981$ (Iksan \& Irham, 2009). Unlike the growth patterns of mackerel scad in the waters of Ambon, isometric, and positive allometric (Pattikawa et al., 2018). The difference in the value of $b$ obtained will certainly cause the difference of length-weight relationship pattern. Differences are suspected due to the influence of food availability, spawning time, as well as fishing pressure. In line with Zahid \% Simanjuntak (2009) that differences in growth patterns influenced by season, Habitat, gonad maturity, sex, food, gastric fullness, health, preservation techniques, and annual variation on environmental conditions.

\subsection{Sex ratio and Gonad maturity level}

Based on observations from dissected fish, it found the fish grows faster in length than the body-weight gain sex composition obtained consisted of 388 males and 322 females (Figure $5)$. The results of the sex ratio of male and female mackerel scad have obtained 1.2:1. The results of the chi-square test obtained that the mackerel scad was no significant difference between males and females of the population in unbalanced conditions.

The sex ratio of mackerel scad that dominant males more than females were also found in the Banda Sea with a ratio of 1.06:1 and at the Flores Sea 1.06:1 (Siby et al., 2019) at Tomini Bay 1.06:1 (Widiyastuti \& Zamroni, 2017) and in the Kendari waters 1.3:1 (Fadilal et al., 2016), in Majene 0.98:1 (Nur et al., 2017). This unbalanced condition between males and females is an indication that the balance of the
Sex ratio of mackerel scad

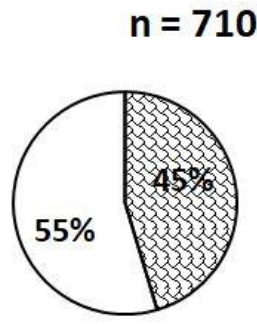

Monthly sex ratio of mackerel scad

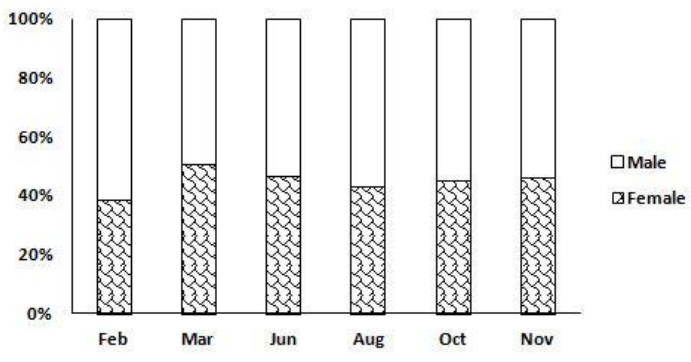

Figure 5. Sex ratio of mackerel scad 

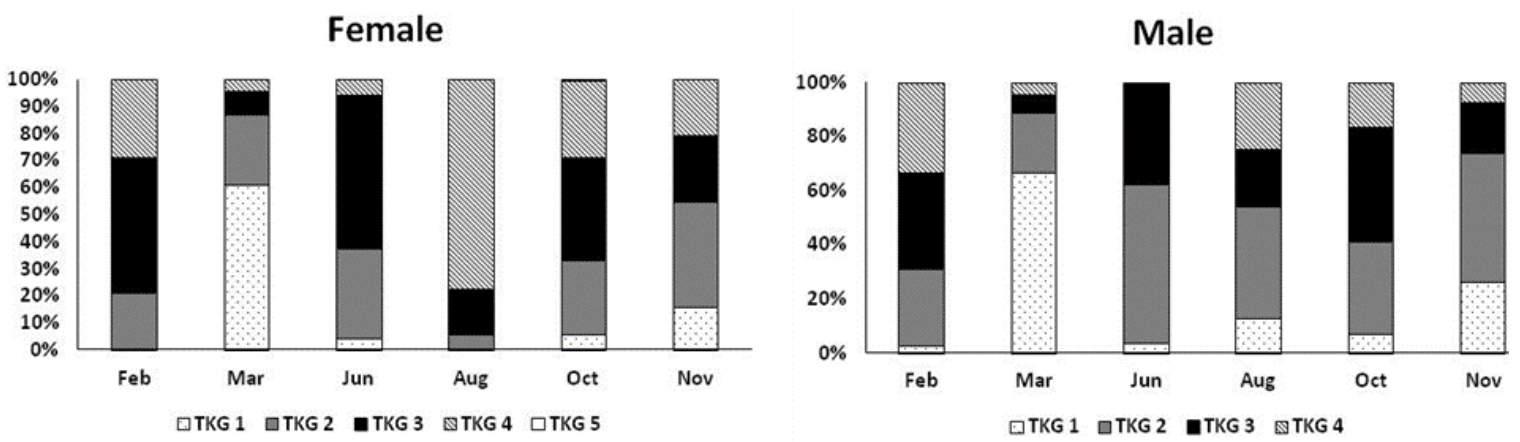

Figure 6. The gonad maturity stage of mackerel scad female and male

population can be disturbed. Ball \& Rao (1984) states that the balance of male and female fish is needed to maintain survival in a population or dominant female fish.

The gonad maturity level is the specific stages of the development of gonads before and after the fish spawned (Effendie, 2002). Immature fish identified had levels 1 and 2, while mature fish have levels 3,4 , and 5 . Mackerel scad in the Indian Ocean West Sumatera waters caught by purse seine was found mostly in the maturity conditions of male and female.

The gonad maturity level varies every month (Figure 6). The female mackerel scad began to be found in the mature level in June and reached its peak in October, the same condition found in the male fish. The maturity condition of gonads mackerel scad in Tomini Bay is widely found in August of males and females (Widiyastuti \& Zamroni, 2017), in the Banda Sea in October and December (Siloy et al., 2019). The difference in results of the maturity of mackerel scad gonads obtained from research in North Maluku waters. Mackerel scad found in mature gonads in March (Iksan \& Irham, 2009) and the waters of Kendari found in April - May (Widiyastuti \& Herlisman, to be published). This condition shows the alleged spawning of mackerel scad as the result of the research Suwarso \& Hariati (1988) mentions the spawn of long-lasting and partial spawn based on a variation of gonad somatic index according to the size and gonad maturity level.

3.4. The length at first capture (Lc) and length at first mature (Lm)

The relationship between the average length at first capture and the first time ripe gonads can indicate the condition of sustainable or not a resource, by knowing whether the average length of the fish has been spawning or not yet (Saputra et al., 2009). The importance of the first-time measurement of mature gonads can periodically become an indicator of pressure on the population (Siby et al., 2009).

The length at first capture (Lc) mackerel scad is $25.08 \mathrm{~cm}$ (Figure 7), while the length at first mature $(\mathrm{Lm})$ is $20.47 \mathrm{~cm}$. This condition indicates that the fish has experienced gonad maturity before being capture ( $L c>L m)$. It means that fish have reached adult size and have contributed to the increase in population. Saranga et al., (2019) states that the condition of one indicator is that the exploitation of fisheries is in ideal condition if the value of Lc> $\mathrm{Lm}$ because if otherwise, it becomes an indicator if the fishing pressure has affected the growth of fish stocks.

The length at first mature (Lm) of mackerel scad was found in different conditions with the results of this study (Asyari \& Herlan, 2013; Pattikawa et al., 2018; Widiyastuti et al., 2020). The variation of $\mathrm{Lm}$ value is also found in some

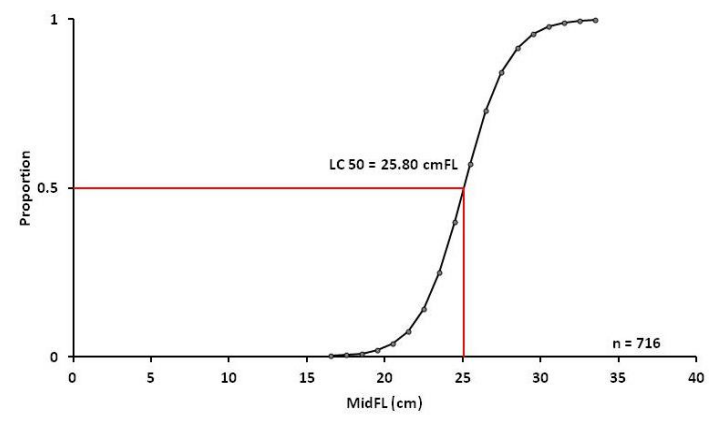

Figure 7. Length at first capture of mackarel scad 
waters as in Makassar Strait $\mathrm{Lm}=25.12 \mathrm{~cm} \mathrm{FL,}$ in Banda Sea $\mathrm{Lm}=25.45 \mathrm{~cm} \mathrm{FL}$, and Flores sea $\mathrm{Lm}=25.86 \mathrm{~cm}$ FL (Fauzi et al., 2012). Previous research indicates that there is a different habitat environment that will affect the difference of $(\mathrm{Lm})$. Added by Agustina et al., (2015) these differences are also influenced by sex, food, hormones, and the environment. The length at first mature $(\mathrm{Lm})$ not always the same size although the size structure of the fish is the same length class (Udupa, 1986).

Analysis of the length of the caught fish and the size of the mature gonad fish are the basis that the condition of mackerel scad fish resources in these waters is still kind because as many fish have contributed to the environment. However, management must be needed to maintain the preservation of resources by applying the rules of using mesh size purse seine by 1 inch by Minister of Maritime Affairs and Fisheries Regulation 71 of 2016. The socialization and supervision on the size of these nets must be by involving various stakeholders including fishermen organizations to jointly maintain the sustainability of mackerel scad fish resources in the waters of the Western Indian Ocean in Sumatra.

\section{Conclusion}

The length distribution of the study ranged from 16.0-33.6 cmFL. Most Mackerel scads are caught by purse seine in mature size. The length at first capture is greater than the length at first mature which is an ideal biological condition for the availability of mackerel scad stock. The Mesh size of purse seine suggests being adjust following the rule $1 \mathrm{inch}$.

\section{Acknowledgments}

This study is part of research activity entitled Research of Biological Characteristics, Habitat Resources and Potential Production of Fish Resources in FMA 572 in 2016. We would like to thank all the team who have helped to collect data. The first author is a major contributor to this paper, the second and third author as a member contributor.

\section{References}

Agustina, S., Boer, M., Fahrudin, A. 2015. Dinamika Populasi Sumber Daya Ikan Layur (Lepturacanthus savala) di Perairan Selat Sunda. Marine Fisheries 6(1): 77-85.

Anonimous, Laporan Statistik Perikanan Pelabuhan Perikanan Nusantara Sibolga Tahun 2015. 2016.
Arsyari, Herlan. 2013. Beberapa Aspek Biologi Ikan Kurau (Polynemus dubius) di Estuari Sungai Indragiri, Riau. BAWAL Widya Riset Perikanan Tangkap 5(2): 67- 72.

Ball, D. V., Rao, K. V. 1984. Marine Fisheries. New Delhi: Tata Mc. Graw-Hill Publishing Company Limited: 5-24 pp.

Effendie, M. I. 2002. Biologi Perikanan (p.163). Yogyakarta: Yayasan Pustaka Nusatama.

Fadilal, M., Asriyana, Tadjuddah, M. 2016. Beberapa Aspek Biologi Reproduksi Ikan Layang (Decapterus macarellus) Hasil Tangkapan Purse Seine yang Didaratkan di Pelabuhan Perikanan Samudera Kendari. Jurnal Manajemen Sumber Daya Perairan 1(4): 343-353.

Fauzi, M., Suwarso, Yahya, M. F. 2012. Status Pemanfaatan Sumberdaya Ikan di Perairan Selat Makassar, Teluk Bone, Laut Flores, Laut Banda: Biologi Reproduksi Ikan Layang Biru/Malalugis (Decapterus macarellus) di Selat Makassar, Laut Flores dan Laut Banda. Jakarta: IPB Press dan Kementerian Kelautan dan Perikanan: 175-189

Hariati, T. 2005. Perkembangan Pemanfaatan Ikan Pelagis Kecil Menggunakan Pukat Cincin Sibolga di Perairan Barat Sumatera pada Tahun 2003. Jurnal Penelitian Perikanan Indonesia 11(2): 57-67.

Holden, M. J. \& D. F. S Raitt (eds.). 1974 Manual of fisheries sciences. Part 2. Methods of Resource Investigation and Their Application. FAO Fish. Tech. Pap. 115 (Rev. 1.): 1-214.

Iksan, K. H., Irham. 2009. Pertumbuhan dan Reproduksi Ikan Layang Biru (Decapterus macarellus) di Perairan Maluku Utara. Jurnal Ikhtiologi Indonesia 9(2): 163-174.

Kerstan, M. 1985. Age, growth, maturity, and mortality estimates of horse mackerel (Trachurus trachurus) from the waters West of Great Britain and Ireland in 1984. Archiv fur Fischereiwissenschaft 36(1-2): 115-154.

King M. 2007. Fisheries biology, assessment and management.Wiley-Blackwell, UK, 400.

Merina G., Zakaria I.J., Chairul. Produktivitas Primer Fitoplankton dan Analisis Fisika Kimia di Perairan Laut Pesisir Barat Sumatera Barat. Jurnal Metamarfosa. III (2): 112-119. 
Nur, M, Al Ayubi, M. A., Suprapto, Omar, S. B. A. 2017. Biologi Reproduksi lkan Layang Biru (Decapterus macarellus Cuvier, 1833) di Perairan Sulawesi Barat. Prosiding Seminar Nasional Kelautan dan Perikanan IV Universitas Hasanudin: 201-208.

Pane, A. R. P, Widiyastuti, H., Nurulludin, Suman, A. 2020. Struktur Ukuran dan Tingkat Pemanfaatan Ikan Lencam (Letrinus lentjan) Perairan Arafura, di Probolinggo. Al Kauniyah 13(1): 128-138.

Pattikawa, J. A., Ongkers, O. T. S., Tetelepta, J. M. S., Uneputty, P., Amirudin, A. 2018. Some biological aspects of mackerel scad (Decapterus macarellus) in Ambon Island waters, Indonesia. International Journal of Fisheries and Aquatic Studies 6(4): 171175.

Pauly, D. 1984. Fish population dynamics in tropical waters: a manual for use with programmable calculators (8). WorldFish.

Rahmadi, P. Puspasari, R., 2015. Dinamika Ekologi Laut Sulawesi (WPP 716) Sebagai Daya Dukung terhadap Perikanan Malalugis (Decapterus macarellus Cuvier, 1833). Jurnal Penelitian Perikanan Indonesia 21(2): 95-102.

Rumpa, A., Isman, K. 2018. Desain Purse Seine yang Ideal Berdasarkan Tingkah Laku Ikan Layang (Decapterus macarellus) dan Ikan Tongkol Deho (Auxis thazard) di Rumpon. Prosiding Simposium Nasional Kelautan dan Perikanan (5):89-98.

Saputra, S. W., Soedarsono, P., Sulistyawati, G. A. 2009. Beberapa Aspek Biologi Ikan Kuniran (Upeneus spp) di Perairan Demak. Jurnal Saintek Perikanan 5(1): 16.

Saranga, R., Simau, S., Kalesaran, J., Arifin, M. Z. 2019. Ukuran pertama kali tertangkap, ukuran pertama kali matang gonad dan status pengusahaan Selar boops di Perairan Bitung. Journal of Fisheries and Marine Research 3(1): 67-74.

Siby, L. S., Rahardjo, M. F., Sjafei, D. S. 2009. Biologi Reproduksi Ikan Pelangi Merah (Glossolepis incisus, Weber 1907) di Danau Sentani. Jurnal Iktiologi Indonesia 9(1): 49-61.

Silooy, F. D., Tupamahu, A., Ongkers, O. T. S., Haruna. 2019. Population Dynamics of
Mackerel Scad (Decapterus macarellus) in the Banda Sea. Internasional journal of environment, agriculture and biotechnology 4(4): 1199-1204.

Silooy, F. D., Tupamahu, A., Ongkers, O. T. S., Matrutty, D. D. P. 2019. Distribution and growth Mackerel Scad (Decaperus macarellus) in the Ambon waters. Internasional journal of environment, agriculture and biotechnology 4(2): 505508.

Suwarso, Hariati, T. 1988. Pendugaan Kematangan Gonad dan Musim Pemijahan Ikan Layang (Decapterus russelli) di Laut Jawa. Jurnal Penelitian Perikanan Laut (46): 1-9.

Udupa, K. S. 1986. Statistical Method of Estimating the Size at First Maturity in fishes. Fishbyte. ICLARM. Philippines.

Walpole, R. V. E. 1993. Introduction to statistics. B. Sumantri Translation (3th edition) (p. 321). Jakarta: PT.Gramedia.

Widiyastuti, H, Herlisman, Pane, A. R. P. Ukuran Layak Tangkap Ikan Pelagis Kecil di Perairan Kendari, Sulawesi Tenggara. Marine Fisheries, IPB (to be published)

Widiyastuti, H., Zamroni, A. 2017. Biologi Reproduksi Ikan Malalugis (Decapterus macarellus) di Teluk Tomini. BAWAL Widya Riset Perikanan Tangkap 9(1): 6372.

Widiyastuti, H., Kuswoyo, A., Tirtadanu. 2020. Perikanan Jaring Bobo di Ambon. Prosiding Seminar Nasional Perikanan dan Kelautan 8(1): 138-143).

Zahid, A., Simanjuntak, C. P. 2009. Biologi reproduksi dan faktor kondisi ikan ilat-ilat, Cynoglossus bilineatus (Lac. 1802)(Pisces: Cynoglossidae) di perairan Pantai Mayangan Jawa Barat. Jurnal Iktiologi Indonesia 9(1): 85-95.

Zamroni, A., Suwarso, S. 2018. Genetic Diversity of Mackerel Scads, Decapterus macarellus (Cuvier, 1833) In the Indian Ocean. Indonesian Fisheries Research Journal 23(2): 89-96.

Zamroni, A., Suwarso. 2011. Studi tentang Biologi Reproduksi Beberapa Spesies Ikan Pelagis Kecil di Perairan Laut Banda. Bawal Widya Riset Perikanan Tangkap 3(5): 337-334. 